\title{
The Gospel of Self-ing: A Phenomenology of Sleep
}

\author{
Kuangming Wu \\ Philosophy Department, University of Wisconsin-Oshkosh, Oshkosh, USA \\ Email: Kmwu2002@yahoo.com
}

Received 14 February 2014; revised 14 March 2014; accepted 20 March 2014

Copyright (C) 2014 by author and Scientific Research Publishing Inc.

This work is licensed under the Creative Commons Attribution International License (CC BY).

http://creativecommons.org/licenses/by/4.0/

\section{(c) (i) Open Access}

\begin{abstract}
Sleep is consciousness naturally folded back to itself in the self-come-home-to-self, to find life nourished, renovated, and vitalized, all beyond objective management. Sleep can never be understood with direct conscious approach, but must be approached indirectly, implicatively, and alive coherently, as tried here. Sleep (A) is Spontaneity, (B) Self-Fullness, and so (C) sleep is life's Gospel of Self-ing.
\end{abstract}

\section{Keywords}

\section{Sleep; Alive; Conscious; Spontaneity; Fullness; Gospel}

\section{Introduction}

Sleep is one basic, common, supportive, and yet quite elusive way of living to nourish and fulfill ourselves, constantly inviting us to mediate on it with care. The direct conscious approach usual in our thinking never understands sleep that is tacitly beyond-consciousness. Sleep must be approached indirectly, implicatively, and alive coherently, as tried here.

Sadly, it is noteworthy that sleep is usually taken as nothing positive. This is so except surprising gems grudgingly admitted at the end of this essay. The Judeo-Christian tradition takes sleep as a simple satisfaction of physical need, or as a symbol of sloth or death. In Greek mythology, Hypnos-sleep is Thanatos-death's twin brother both Nux-night's children, nothing positive. Buddhism takes sleep as ignorance, one of Eight Entanglements 八緾 away from Enlightenment. Sleep is evil in Buddhism, explicated in Idealism 7, Mahayana Truth Chapter 2, On Chü-Sheh 20, and Essential Survey of Buddha, etc. Confucianism is undecided on sleep (Wu, 1990). Christianity notes that the martyr's death is sleep, and a young man's fall in sleep from the third floor caused no death (Acts 7: 60, 20: 9-12). Only Chuang Tzu in philosophical Taoism is quite vocal on the ultimate 
positive significance of sleep. But at a deep level, Buddhism stresses awakening from sleep-ignorance to the sleep-like Void, Nirvana.

So Buddhism seems similar to Chuang Tzu's Great Awakening 大覺 to sleep; its power is fantastic, the Void of all voids (nothing moves freer than nothing moving). Still, Taoist nothing is 虛-room; Buddhist nothing is 空-ignorance obstructing progress. So, Taoism can, but Buddhism cannot, see positive potentials in selfemptying sleep; only Chuang Tzu sees sleep’s vast positivity to enrich Buddhism and Christianity. "Sleep" is where philosophical Taoism is explicating life-vigor well-up, daily, to cipher health.

Sleep is so common that no philosophy, psychology, or religion would deign to consider it as such, but observe it outside to miss it, the spontaneous human basis. Psychology looks at sleep from outside (REM, five physiological stages, etc.) to miss our inner undergoing of sleep, as focusing on color-wavelength misses "color". Spontaneous sleep can/must not be considered; sleep is unintended, and none can consider the unintendedtrying to catch where I fall asleep misses sleep. We must meditate Taoist way on what sleep is and how life-essential it is. Then we are surprised to find how sleep nourishes, to fortify and fulfill the self into well-slept sleepinfused life. Sleep (A) is Spontaneity, (B) Self-Fullness, and so (C) sleep is life's Gospel of Self-ing.

\section{Meditation on Sleep as Spontaneity}

Life can go on only with sleep that yet wipes life blank as tiny death. It is natural to take sleep as a tiny death; Zen Buddhists, Tibetan Buddhists, and religious Taoists do so. They may see sleep-death followed by wakeful life-rebuilding, but how life can be rebuilt after dissolution is unclear. This essay develops an alternative thesis that sleep-as-“death" is death-of-awareness in spontaneous self-homecoming, to replenish the self. Nothing is triter than sleep; no philosopher considers it except Aristotle who squeezed it into preformed categories to miss it. Indeed, there was no article on sleep in any dictionary or encyclopedia of philosophy. Aristotle asks if sleep is of body, soul, both, or half of each, if sleep is contrary to waking, actuality or potentiality, etc. (Barnes, 1995). Sleep can release us from inhibitors, psychic diseases, Freud's wakeful description says of sleep's effect, found by imposing objective categories on dreams (Freud, 1913). So we leave thinkers stuck in wakeful analysis, and Chuang Tzu is here, smiling with a story on sleep in poetry rough and pungent (Chuang Tzu, 22/21-24).

[Uncouth Mr.] Chew-Chipped asked [cultured Mr.] Clothed about Tao. Clothed said,

"You right your form, one your vision-

Heavenly Harmony will arrive.

Fold your wit, one your bearing-

Spirits will come homing-in.

Virtue will be your beauty, Tao will be your lodge-

You gaze like a calf new born and not seek causes.”

Words not over, Chew-Chipped fell fast asleep. Clothed, much pleased, left singing,

"Form like a withered skeleton, mind like dead ashes, ...

Dim, dim, dark, dark, ...

Mindless and cannot consult with,

What man is he!"

This story praises sleep as life homecoming to itself, this way. For Freud sleep shows an instinct to return to the womb we left, an infantilism breeding psychic problems to miss the womb as the self that sleep-heals, as he look at sleep from outside (Freud, 1950). While awake, I am conscious, stretched out to not-I’s. My stretch-out tenses me, tires me. Conscious is "com-scire, with-know", conscious of the not-I. So, being conscious stretches I to not-I. I need to fold consciousness back into itself, come home. Consciousness folded back turns "I" notconscious asleep, as a baby sleeps so alive, not dead unconscious.

This "I fold back to ' $\mathrm{I}$ "” is "A is A" back from not-A, "A is not not-A"; it is the basic law of identity existential, the Tao-Way of things, sleeping vitalizing. Mr. Chew-Chipped slept to exhibit the Tao that Mr. Clothed merely explained, to elate Mr. Clothed. Our essay here unfolds such basic "sleep" alive.

No one asleep can be unreal or deceptive; sleep-authenticity replenishes self-authenticity. No death replenishes, yet sleep is often compared to death. We are easily awakened from sleep but not from coma or death. After sleep we are refreshed; "after death" is senseless.

Lacking response to outside as death, sleep is yet contrary to death. Babies sleep often to grow; sleep means life. Not dead or awake, sleep regularly interrupts activity to replenish life. Activity-interruption depicts not-life; 
replenishment describes life. Sleep is a not-life invigoration of life. None noticed such extraordinary contraries in one; "sleep treatment" in ancient Egypt and "sleep"-therapy in psychology today exploit sleep's healing efficacy, uninterested in what it is or why it benefits.

Here are four routine points. 1) life moves self-conscious; I know I move; 2) life yet stops its self-move self-conscious to "fall" asleep unawares; 3) life's self-stoppage vitalizes; no life-stop, no life, incredible! 4) the oddity occurs regularly. Do trees sleep? They take rest, stop activities every night; we just do not call their rest "sleep."

No writer deigns to write on this commonest oddest routine. Many Greek myths surround Hypnos-sleep, son of Night and Darkness, twin brother of Death, father of Dreams. I chanced on an odd poem, "On a Bird Singing in Its Sleep" (Frost, 1995: p. 275). People write around sleep. Our task is to probe sleep tricky, to probe aware into sleep unawares!

Natural sciences all-knowing tell us from outside on how sleep goes, but not what it is. Such is the stunning oddity of "sleep", so routine yet so odd, in 24 hour rhyme without reason, to recreate life. I call it the Gospel of Self-ing. We ponder on sleep, and we realize how sleep enlightens, why we sleep, how it turns one into oneself, and what it means. Nothing is more common more important than sleep unawares, yet seldom is sleep recognized as nourishing. Five roaming subsections here describe all this.

\subsection{What Dream Is}

Dream is less mysterious than sleep; we dream in sleep (nightmare) and awakened (daydream), so dream is not sleep or awake. What is it? For Freud (1899) and Jung (1974) dream occurs in the unconscious, individual (Freud) or collective (Jung) - yet dreaming unawares is not unconscious, for "unaware" is not "unconscious", and dream is half-conscious (Gibran, 1923); psychologists and philosophers can consciously consider dreams but not sleep non-conscious. I am unaware of literature on sleep itself, though poet-writers often chant on dreams, as Gibran did.

What Freud and Jung may have meant is that dream is non-self-conscious. Non-self-conscious sleep is not un-self-conscious, much less unconscious death. self-conscious act splits self into observer and actor, self-asanother, to breed self-deceit and other-deceit. Paul Ricoeur (1992) mistakenly takes the split self as our original nature. Human nature is originally one but fragile, to easily split into self as another. The "other-ing" is so deep that Jean-Paul Sartre takes "deceit" as our innate "Nothing" (Sartre, 1943). His is an ontological phenomenology gone awry. Non-self-conscious sleep reverses this trend; the self closes its "eye" to otherness to become childlike whole.

\subsection{Putting Sleep into Waking Life}

"But how do I put my sleep-unity into waking activity? Do I sleepwalk?” We sleepwalk sky-walking to StarTrek. My boy Peter said, "I have three names, me, myself, and I, Dad. Bye!” and off he went playing, with his wonderful triune self; he freely "sleep-walks" to "skywalk", "no-wing flying, knowing not know", naturally.

Georg Kulenkampff (1898-1948) plays his rich enchanting Stradivarius violin. The music flows on its own as he lets music go. Nor does he show trying. All this no-show is no-do, to charm irresistibly in sleep-like naturalness. Sleep is no-do life-music no-showing, alive no-act, closed to outside responses, and it turns powerful. "How could it happen?"

Polar bear cubs I watch tell me not-telling, that I must forgo crafting, cub's way. No-craft then crafts cub to self-craft, dross-dropped. Tommy shouts "No nap!" "OK, no nap, Tommy. Sit here, then, and Mom tells you a story, ok?” Tommy nods. "Once upon a time,” and he hits the pillow; Mom tucks him in, softly. Mom no-did; her “no” infuses sleep cub-natural nothing done, and nothing not done 無為而無不為 (Lao Tzu 37).

The sleeping self is with itself in itself, nourished. Sleep-replenished self is sleep-alert to the outside fittingly. So, strangely, self fully awake is fully asleep, not contrived, Greatly Awakened to sleep. Kids sleep often; doctors on call doze off at any moment, to snap fully awake when called. Catnaps are wholesome. Come home to sleep-unity, I turn sleep-one, not sleepwalk self-collapsed. Self examination must be examined, and this metaexamination turns me non-aware, as my fatigue calms self-consciousness to fall asleep aware non-aware, heart still pumping.

Sleep joins conscious act to non-conscious fall-into-sleep despite me, as falling in love. Unifying conscious spontaneity and non-conscious falling asleep reunites the split self into the self natural one. This act of no-act, 
self-folding-back in sleep daily, replenishes. Sleep is the test of my health, physical mental. We must now think on what sleep-health consists in.

\subsection{Sleep as Spontaneous}

Sleep is spontaneity elusively incarnate everyday. I could, say, converse with an objective analyst on dream, and I would be jolted into seeing what spontaneity is not. He may say, "In a dream, I can watch me flying, so I am not un-conscious in sleep. Such objective analyst is usually a he; ladies are more perceptive. Heidegger (1957) says of self-identity as belonging with oneself in thought. How could this identity not be conscious? So, self-identity is not self-disappearance."

This is a familiar objectivist critique to miss sleep-spontaneity; dreaming to watch me flying is just that, dreaming I am flying, not watching. Heidegger engages in logical explication out of spontaneous understanding. His "self-identity" is a formal description; the dream undergone is spontaneously undergone.

"But the sense of I-ness is active in sleep and dream." This statement is made outside sleeper/dreamer or after sleep, outside in time, to understand no personal undergoing. "But what you object to is objective explication, not Kant's or Heidegger's transcendental explanation.” This objection is tidily logical. To explain logicizes to externalize, analyzing, reckoning, ordering, as "logic" (legein, logos) means (Wu, 1998). Only an external observer or retrospective reminder analyzes to explain. Actual spontaneity of sleep is incorrigibly internal, ineffably concrete, inexplicable.

Millipede was happily walking till asked by leg-less Snake how he coordinates his million legs. Millipede stopped to ponder, and could not walk (Chuang Tzu). Chuang Tzu 17/53-60 is a story of stages of progress in spontaneity, awareness non-self-aware (Mair, 1994). Non-self-conscious awareness is elusive; it moves legs till made aware. We must attend from ourselves - vanish to awareness - to play piano (Polanyi, 1959). He devoted his life to explicating this life-dimension. Self-vanish—dying to self-awareness—enables self-expression; sleep reenacts self-vanishing spontaneity each night.

Tacit sleep self-vitalizes, as we must be sensitive to nuances of self-expression. Kant and Heidegger are not incorrect (or correct), but their mode of expression is off. Saying "I love you" can solidify or destroy love, in admiring confession or as description, disdain or sarcasm. Kant/Heidegger's formality misses such lived modes of saying.

Saying aloud "love!" can destroy love; formally saying "behaving morally" can demolish morality, to objectifies to immobilize; analyzing them into components to pack into formulas kills life. What said must be conveyed hidden in how said, as the subject must vanish to be real. Objectivism forces tacit actuality to appear, to miss to dissipate its reality. Now, sleep is life's supreme tacit ever hidden unawares, to authenticate to replenish the self. "How does sleep do so?"

\subsection{How to Sleep-Spontaneity}

Socrates' assiduous self-examination the high act of split-self would have immobilized him in an infinite regress of self-examining self-examination, etc., were it not for his reliance on inner Daimon he followed; it is his Self at bottom. He did not examining It so that he can examine himself.

I am in rage despite me, in self-forgetting engagement, in enraptured enjoyment of art, and in archery as I become that arrow about to fly. I am self-aware, supported by rock-bottom I-ness unawares. This I-oneness guides me to achievement (Chuang Tzu, 1970); irresistible powerful I turn at one with me, as I am then at one embodying the world unawares. Chuang Tzu's (1970) Chapters 19 and 23 (its conclusion) have examples; actually his entire corpus is about this state, in it to attain it is to "nourish life", as Chapter 3 is so titled. Sleep speaks the collective archetypes (Jung, 1973), homing me into the world. Common sense concurs with him on human solidarity with the world, yet hesitates at his mystical identity of humanity.

Closing the self-conscious access to outside paradoxically lets the world to open its access, as in Cook Ding and Skywalker (to explain later), in the sleep-unity in "I" wakeful, to "one oneself," to become one with the situation, free in situ, "awakened to sleep”, sleep-empowered.

\subsection{Awakening to Sleep}

Awakening to sleep is not Buddha's awakening from sleep. Chuang Tzu's butterfly-dream urges us to awaken to 
the fact that we are unsure of awakened or asleep, awakened from being cocksure of awakened when we are actually asleep. Chuang Tzu proposed it to end Chapter Two; it is incredible, as we ordinarily takes all this for granted.

This is the Great Awakening to sleep. An explanation is in order.

Awakening is becoming aware; awakened from awakening is to be aware of being aware, to be one-withoneself as in sleep. It is to wake up to sleep, to become one-asleep, sleep-one, to re-turn to sleep, to turn from my turn-from sleep, to extend nightly sleep-unity into day-activities; sleep begins all to empower all acts, nature-invincible, immune from natural disasters as nature is immune. The ultimate non-self-consciousness is sound sleep, non-conscious homecoming to self each day to replenish into self, to conduct oneself in lively child-spontaneity. Kids live dreams in life-vitality sleep-spontaneous.

Great is one who loses no baby-heart (Mencius 4B12); one's baby-heart is full self, as the child sleeping wrapped in self-full-ness. Such a one is a Great Person 大人 in power, integrity, and sleep-full freedom. We must see how practically all this happens.

\section{Meditations on Sleep as Self-Full}

\subsection{What Sleep Is}

A living being is self-active in response to not-self, yet living being also sleeps to stop self-acting. We ask why life is regularly punctured by small death, sleep. This query assumes sleep as waste; a third of life is wasted in "idle" sleep. Such interpretation shows we miss what sleep is. Interestingly, only after sleep do we realize it refreshing. Sleep is a having-been, a "nothing" in waking life, and yet as "death" to awareness, as no-self, sleep gains the self in primal life-vigor of childlike oneness; only while awake can we be aware that sleep makes life whole.

We think the day begins at dawn, leaving hours from midnight to morning in a limbo, so the day must be unrelated to night's sleep, or else the day must begin sleep-infused. The first idea takes night-sleep as day's death, contrary to the fact that sleep refreshes us but death does not. So we must accept the second idea that the day is fulfilled by night's sleep. Isn't it surprising? Another surprise is this. The day begins at dawn to end at nightsleep, “end” as "finish" and "aim”; night is day's crown. Sleep is the aim of day-activities; we live in sleep to live for sleep, to sleep!

Both surprises oppose us taking sleep for work, to support common sense that the day begins at dawn, thanks to the night's sleep. Life is lived for health; we are happy when we can sleep well. We succeed in daytime because we are well-slept. Infused with sleep, we accomplish. Sleep initiates and fulfills waking life. Thus sleep deprivation is one torture to deprive the self; it is a murder.

"Why awake, then?" We are awake to be happy sleep-infused. "Why sleep?" It is essential to making life whole. Sleep answers why we are awake, and how best to be awake. This conclusion reverses our assumption, "Sleep is a waste of life." Sleep is a non-self-conscious self-ing. Sleep, self, and sleep-infused self living its dreams, all three revolve around sleep into life's good tidings.

\subsection{Sleep as Life's Good Tidings}

In sleep, we do not deliberate leaving open receptors to outside. Sleep closes my eyes to dealing with not-I, settles me in me to self-nestle, self-return, to home me. Let us unpack all this to surprise ourselves into joy. Sleep and self are a twofold event in sleep-as-self-ing. Its contrast, wakeful daytime activity, intimates this truth.

By the day's end I have had enough, having been ravaged by daytime pursuits that have torn me from me. Writing all this wakeful aware can be a self-forgetful joy sleep-like, to fulfill me as in sleep. Lucidly awake aware, I think getting things desired would satisfy me; I want (lack) to crave (are crazy) after desirables. Sadly, wakefully pursuing not-I, I become not-I, going farther away from me my real desirable. I am un-self-ed in pursuit of things wanted to fill me; as soon as I get what I wanted I have to start a new chase for more things; I cannot find me in things not I. Genesis 2 describes this sad situation of self-loss in eating the desired fruit, a thing. This situation differs from Sartre's (1943) hunger that is killed by feeding it, in Being and Nothingness.

The more I get, the more I want, and the less I am. I turn hungrier the more I feed on not-I.

A quip shows this tragedy: "Love of money is the root of all evils." Love of money is love-of-things. I think money is a blank check for anything I want, unaware it lulls me away from me. "Money is the root of all evils" 
means "Things desired are the root of all evils, loss of self."

The "evil" here is not "things" or "desire" but self-throwaway in pursuit of not-self, thinking I am pursuing my true desirable, me, unaware of self-loss; this describes the risk of wakeful engagement in things, self drained by money. I also dissipate as I "manage business", money-mind often machinating. "Often" cautions that we can be authentically involved in the machine and/or money. We can enjoy dealing with money to help others, or operating a machine engrossed with its whirring mechanics, being at one with a computer project, or composing on computer. The point is not the engagement itself but our attitude in it. "Machinating mind" separates me from me as I "do" things. Money-machine-mind separates the self, self-engaged to self-contradict to harry me away from me.

Thus the day's hustle and bustle ravages me; I am tired, and night comes for fatigue to lull me to sleep. Those who in sleep still busy themselves with daytime money business get ulcers. "Sleep without sleep" disturbs sleep; being "awake asleep", sleep infuses the self. Difficulties falling asleep show my "psychological disorders" to prevent my homecoming to me. "I can sleep" is an ultimate bliss resolving I-conflict.

Now, there is self-loss and there is self-loss. Self-obsession loses the self; self-return gains the self. Loving money to pursue things is I-obsession to lose me; losing me involved in engaging the other-me gains me in a sleep-like spontaneous I-return. In all this, I am lulled to me at night; naturally submitting me to me sleeping heals all self-harrying, self-contradicting self-separations, setting in order my self-house. Nothing is more nourishing than my homecoming.

In dreams, fantastic or realistic, I reenact what I understood or underwent the day before, to settle account. In dream reenactment, I stretch my imagination, my inner arm, to readjust to cleanse me. This fact supplies a rationale for psychological exploitation of dreams for therapy. In dreamless sleep I just am, nestled in the "amorphous non-entity", the home of me. Here is Chuang Tzu's primal Mr. Hun Tun who concludes the Seven Inner Chapters (7/33-35). In sleep no-do, I am not self-conscious not-think, but am, free-floating in I-know-notwhat (dreams forgotten), I-know-what (dreams remembered), and I-know-not (dreamless sleep); I am self-unaware (no-wit, no-self) in sleep.

Wakeful lucidity of awareness engages me in outside world, into which I am sucked made less; sleeping non-self-aware returns me from outside to nourish me. Sweet dreams dissolve daytime frustrations; nightmares shake me loose from abrasions; dreamless sleep nestles me at home where I just am, a baby in mother's arms who is me the self asleep; wakeful attending to outside "outsides (verb)" me into machine-mind; sleep cuts me from outside to "inside" me, to "self" me home to me. This view is an alternative to Freud's dream as symptoms of psychic disease. Observing sleep from outside splits me, as psychologists since Freud do; daily simple sleep in I-at-home heals wakeful I-split, being-schizophrenia. The crucial juncture, "he came to himself," starts the prodigal son's weary homing steps (Colman, 2001; Ivker et al., 2000). Moreover, Luke 15:17; the King James Version accurately and literally renders the original, "he came to himself." It is the Taoist "gospel of sleep," the self's return (not Freud's "regression") to the parent-home (not Freud's "womb") of the self. Such is the structure of how sleep heals us into our pristine self, in "non-self-conscious self-ing". We must ponder on sleep as self-ing.

"Now, sleep is my intimate affair, irrelevant to the Beyond, right?” Well, sleep creates me anew each day, beyond my awareness. These three features of sleep are religious, pal. In sleep, God created Eve (Genesis 2: 21); sleep is sanctum sanctorum of Tao (Mr. Chew-Chipped). Sleep is the Beyond daily incarnate. We are awed that such awesome creation-continual takes place sleep-unawares. Sleep intimately tells of the Beyond hidden unknown beyond me. Now, our journey into stunning sleep continues.

\subsection{Non-Self-Conscious Self-ing}

Sleep is non-self-conscious self-ing, a homecoming-to-self, an oddity. In usual homecoming the one coming home is not the home; in coming-home-to-self, the one-homing is the home. In sleep homecoming, the sleeper is two in one, home and one-homing. We call this situation "spontaneity".

We can understand such sleep-oddity in two ways, both to non-self-conscious self-ing. The first is to take sleep as coming home to spontaneity. To exist is to stand out, and yet, oddly, spontaneity stands out existing as not-"existing". "Existence" is made of "ex" = out and "sistere" = stand. Trying to fix my exact point at falling asleep, I end up sitting up all night. Self-as-home spontaneity in sleep vanishes when looked-at, to split "home" from "homing one", and sleep-spontaneity vanishes. Spontaneity is odd, sleep is spontaneous, so sleep is odd. 
The second understanding of sleep-oddity is by Chinese painters seeing things as things see. The painterly self vanishes in things that appear on canvas as they are, as the painter self-fulfills in them, unawares. In Wang Kuo-wei's 王國維 celebrated “milieu of no-self 無我之境”, (Wang, 2002), one sees things as things see, as in sleep the self lives in their eyes their perspectives, at one with them, no self-self rift, no self-world rift. No-rift is the milieu of home-as-homed-self.

Ordinary vision is magic. I see things and see no seeing me, or see me seeing and lose seeing and things seen. Seeing things loses me in things I see. As the thing appears (to me) I disappear (in it); I am healthy as I can see unawares. All this describes sleep; I vanishing into not-I at home is my health sleep-whole to enable healthy seeing-wholeness. Painting is a common seeing captured on canvas, where seeing I and things seen are one, as sleep is a common once-a-day happening realized into the next day.

Things in painting see and are seen; seeing and seen join, and the world comes home alive. Painting is the home of things painted; canvas enables things to home pellucid, a home-as-things-and-self. That is, now the world is the things', not the painter's. The canvas is things' home; the self is a canvas as it vanishes in things to let them freely appear. Sleep the no-self canvas is self vanishing; dreaming is the self disappearing in things to become things appearing, for the self to home itself, for things to thing themselves. In sleep, dreaming, I become butterfly, tiger, hill, pine-wind, become as I am in them as they are. Sleep homes me in things.

Things-seen-seeing describes spontaneity, to point to self-invisible, no-self. The law of identity is in logical maneuvers, assumed; self-identity is in living non-self-aware. What logical demonstration assumes cannot be demonstrated; what living assumes cannot be made aware. Aristotle said so in Metaphysics, as its Book Gamma began. All later philosophers said so, too, including Kurt Gödel's famous "incompleteness theorem”. The laws of identity and self-identity work invisibly, unawares, in spontaneity in sleep. Sleep actualizes the law of selfidentity of the self, the world of self-integrity. We here revive Heidegger; his formal exposition of self-identity muffled to miss this lived self-identity of the self as alive as child.

This invisibility is the self's home, and to sleep-return here is life's be-all and end-all. Thus sleep is lifeintegral life-constitutive. One who sleeps is real; one who sleeps not is lost, "self-discarded 自棄” (Mencius). Sadly, none can help a self-discarded one, not even by persuasion. Only persistent evoking, motherly waiting, and softly patient patting on the sleepless one to sleep, can call back a wasteful wakeful wanderer home to sleep to the self. Now that I regularly fall asleep, I must live out sleep-filled life self-full.

But, though similar to seeing, sleep is yet more mysterious than the magic of seeing. Sleep is undergone. Strangely, this sleep-undergoing is a "no-self milieu" that is all-blank; I close my eyes, and then turn open-eyed awake, and the clock tells of some hours elapsed. Only then do I realize I have slept. This strange sleep-experience contrasts sharply with seeing-experience.

In seeing, I cannot see me seeing; I cannot be objective about me being objective, but I am aware enough to feel that I am seeing. It is subjective integrity essential to the "I". In sleep, however, I am not even aware that I am sleeping-now; sleep is felt [1] after waking up, and [2] often as a pleasant after-effect of having been put together. Feeling fit self-composed after sleep certifies that I have slept. In fact [1] is more certain than [2]; I may feel I need to sleep more, but such need also certifies that I have slept.

Thus, sleep is certified only [a] retrospectively [b] by me; sleep is a quite mysterious retrospective introspection, impossible for objective inspection. Sleep assures me that subjectivity is absolutely certain, to correct cocksure certainty of objective science. Objectivity of scientific validity is certified by asymptotic consensus of scientific community. Subjective certainty of sleep, in contrast, is solitary, immediate, retrospective-introspective, and incorrigibly subjective.

None can doubt that "I have slept”; we can correct Descartes and say, "I have slept, therefore, I am.” Now this statement has a complex and mysterious story to tell. Sleep is my undergoing unawares (how could an undergoing be unaware?), and for all its being unaware, sleep is far from being uncertain (how can certainty be unaware?). Sleep-experience is self-certifying; if I am aware I have slept, then I have slept. None can doubt my certainty after I realize I have slept, though this incorrigibility is realized retrospective-introspectively alone. We just elaborated on the waiting father in Jesus' story of the prodigal son (Luke 15: 20). This is remarkable because here is no separate "father"; the father is one's true self, the prodigal son is one's actual self.

Now here is an exciting spinoff. Sleep-infused activity is powerful as I am well-slept at one with myself, all of a piece, in total-self-ed engagement (how could self-full be self-forgetting?). Here I am wholesome enough to be able to afford to self-forget in spontaneous engagement. Self-forgotten, I cannot say "I forget me," as in sleep I cannot say "I am sleeping." Thus sleep shares with spontaneity self-forgetting; in this "no-self milieu" the self is 
so full as to self-forget. Full of self-presence is no self-presence, sleep-infused quite powerful, devil-may-care.

\subsection{Living out Sleep as Self-Fullness}

“Doesn't all this amount to sleepy uselessness? Must we not concentrate on daytime task, never be self-abandoned in sleep?” Now, make no mistake about it. The entire religion is devoted to spreading the Gospel of sleep-self-ing depicted above, though it is called by different names, and religion is a supreme task of concentration far more serious than daily chores, to support daily chores.

Christian prayer drives out demons, its faith moves mountains, to let the dead bury the dead, selling all, "hating” my family, just to follow my Origin. Buddhism's Samadhi and dhyana spread to Japan as san-mai 三昧 and zen 禪, supreme concentration, to nourish haiku 俳句, art of tea 茶道, flower arrangement 生花, sabi 寂 and wabi 伦, and swordsmanship 武士道; the Japanese life-ideal is suffused with sleep-charged concentration. Chuang Tzu's divine man 神人 is True Person 真人 with divine arts in sleeplike cleaver-dance with bull (3/ 2-12), to manage things by sit-forgetting 坐忘 (6/92). The ultimate of True Person is "sleep" quoted a while ago on M. Chew-Chipped (22/21-24). Later, On Sit-Forgetting 坐忘論 by Ssu-ma Ch'eng-chen (pp. 647-735) 司馬承禎 (臺北市三民書局, 2005) programmatized away Chuang Tzu’s original spontaneity.

Children take to all this sleeplike self-full-ness unawares as fish take to water, living this optimum self in situ; they are-there, so children sleep often, whenever they want, and wake up ready to eat and play to the hilt, pep-full. Sleep-charged, they are the focus of praises of all religions. All myths are built on this power dubbed "meditation" "sleep"-full, called "awakening to sleep" and "sleep-infused" power in self-loss, as kids at play totally uncluttered by irrelevant considerations.

There is self-loss and there is self-loss. Self-loss can self-authenticate unawares, or can turn self-dissolute, obsessed with "my things". A musician self-forgotten, lost in music, gains herself in music; self-obsessed musician obtrudes to kill music in selfish prodigality, to discard the self. The self can dissipate in "drunken living, dreamy dying”, or be sleep-infused, self-full. Sleep-infused life heals life to sleep-dissipation; sleep composes the self, self-composed.

Self-abandon self-nourishes; self-abandonment divides to dissipate to discard the self. Caution divides consciousness; concentration unifies the self unawares. Sleep self-forgetful in self-abandon nourishes concentration. A well-slept person is full, effective, alive as divine artwork; meticulous caution only gets in the way. Chuang Tzu (3/2-12) gives a celebrated story of Cook Ting; its excerpted gist is here, sleep-filled.

After nineteen long years of wary wakeful toil at chopping, hacking, and breaking, Cook Ting's senses and wits, consciousness, now ceased in sleep-in-the-acts, tracing the thing's inherent-so, vanishing in his thick-less knife. He-and-knife quivers with the ox, dancing through its spacious interstices, and the ox loosens itself, falling home to the ground. Holding the knife he looks around-lost, hesitant, as if incredulous of what occurred. Then, good-ly wiped, his knife calmly stores away. What nourishment, what fulfillment!

Cook-and-knife is the self dancing with the ox of the world. The knife asserts itself as it progresses, but the cook asserts not, for his senses and wits stop. No wonder, not cut, the ox loosens itself to fall to the ground its home. The non-aggressive self achieves not achieving. Doing nothing (the ox is not cut), nothing is left not-done (the ox self-loosens). Accomplishment occurs in no-accomplishment. Today's movie sees the same happening.

Toward the end of "Star Wars", Luke Skywalker turns off his computer, cuts off his senses from things rushing onto him from fast-coming routes. He lets himself go in a tiny flying skiff zooming in narrow crooked paths, to end in a smashing conquest. Luke cuts not cutting the ox of the world, as the Chinese character for "thing 物" pictures how ox-things 牛 appear by cutting(-not-cutting) 勿, and “loosening 解” comes, 角 + 刀 + 牛, cleaver 刀 going between bull's horns 角, going into the bull 牛 that loosens itself 解.

We now understand Chuang Tzu's story, quoted above (22/21-24), of how Mr. Chew-Chipped was uncouth enough to ask about Tao the Basics of things, then dared to fall asleep during Mr. Clothed's answer, who saw through the sleep to walk away elated. Mr. Uncouth's spontaneity fulfilled the answer unawares to turn Mr. Cultured elated.

\section{Concluding Meditation}

“But isn’t it odd to extol a sleepy life? Isn’t it illicit to praise idleness? Even “idleness” was praised by Tanizaki Jun'ichirō, Lin Yutang, and Bertrand Russell. My “Tanizaki's 'Theory of Idleness (Randa no Setsu)' and Japanese Philosophy” admires it (Kess \& Helen Lansdowne, 2005; Lin, 1937; Russell, 1935). 
A well-slept person is effective, not in his sleep but has slept. Don't be confused; we cannot sleep through life, comatose-idly. Your correct observation separates sleep from awakened day-engagement, missing how the two are intimately linked. Our responses clarify how central sleep is for life at all times, not admitted dismissively as having slept.

Yehudi Menuhin (1979) quoted a conversation of A. M. Abell with Brahms.

Abell asked. If Brahms had had the same experience as Mozart had when he had a flow of ideas, "like a vivid dream". "Yes, When at my best it is a dreamlike state [when] ideas flow" "Are you conscious [then]?" "Certainly; otherwise I would not be able to write the ideas down as they come." "Have you ever lost consciousness?" "Yes, sometimes. I fall asleep, and. lose the ideas." "Can you do anything to induce [it]?” "Yes, I have to be absolutely alone [, otherwise] I cannot. Compose.”

Here is the link and the distinction between simple sleep and sleep-like creativity. The key is "well-slept"; it can mean "having slept well" or "well infused with sleep". The two are distinct but linked. In sleep we come home to our self; here, as homed and at home are synonymous, so sleeping and having slept are linked. We must sleep well and live sleep-infused, in refreshed vigor.

The story of Mr. Chew-Chipped underscores how crucial being integral-as-in-sleep is, not self-abandonment in not-self, “drunken living, dreaming dying 醉生夢死”, but a spontaneous self-enfoldment for the self to grow into self. Cook Ting and Luke Skywalker are not asleep or sleepwalking but fully awake toward sleep, as Ting's wits and senses stop and Luke cuts off senses and computer calculation. They are "awake asleep”. To sleepwalk is sleep-overwhelmed; to be "greatly awake" is to be awake-to-sleep, sleep-embodied, sleep-full, at home in oneself as in sleep.

Ting and Luke are ecstatic, standing-outside their usual self. Being enthused, divine-entered mad, is madly extra-ordinary from usual perspective. "Mad" indicates mistaking our usual state for our normalcy, for "usual" is not "normal". Normal state is where "we are where we are"; usual state is where "we may not be where we are." "Ecstatic madness" is the normal state we usually miss being, for we fail to sleep truly, to integrate sleep-authenticity into awakened living, in short, to be awake asleep.

Be awake asleep, and our another common idea, "We sleep to start a new day," takes on a new legitimacy. We are here not just awake (to handle money) or just asleep (in sleepwalk). Being sleep-infused, integrated with sleep-authenticity, is sleeping to solidify our real ideal in our common day-practice.

Chuang Tzu's butterfly dream story (2/94-96) shows a true awakening-sleep:

Yesterday, Chou dreamed to be a butterfly;

Flitting, fluttering, [he] was a butterfly...

[He] did not know "Chou".

Suddenly, [he] awoke.

There-thoroughly, thoroughly, he was Chou.

But now he did not understand-

Did Chou's dream make the butterfly?

Did the butterfly's dream make Chou?

Chou and butterfly - there must be a distinction.

This it is which people call "things changing".

The story says Chuang Tzu realized he had always been sleeping, as Chou dreaming or as butterfly dreaming. To wake up to this sleep-situation is Great Awakening, a full living, where things are one, awakening and asleep-dreaming, knowing and not-knowing, Chuang Chou and butterfly, mutually distinct and inter-homed, vanishing into each other, inter-wondering in interchange inter-changing, all in a self-other unity in distinction.

Greatly Awakened to sleep composes the person whole, one in two, in day-activity with not-self, in spontaneous night in oneself. Ting is the knife in the ox (asleep), dancing with it (awake); Luke is the skiff (asleep) freely zooming through (awake). Their excellence radiates in the day well-slept, sleep pervaded, self-homed, integrated-in-counterpoise, to divinely accomplish the task. Sleep returns us to ourselves, to bring ourselves with our world. Get things done while awake, and we are lost. Engage things self-forgetfully, and we, sleep-spontaneous, are home, fulfilled. We can now sleep well to live our dreams.

Sleep is sleep and creativity, creativity. Picasso's painting is not his sleep. But literalism is lava to the creativity-volcano. Dream is not sleep but manifests it; sleep is not creativity but evokes it. Lava is volcano-produced; sleep is not creativity-induced but nourishes it in non-self-aware unity with dreams, as we create to actualize our dreams; sleep is an ecstatic self-self unity to creativity, humanness at its highest and truest. We must live sleep- 
filled to creative dreams- to create.

Sleep is thus life's Gospel of Self-ing. A daily nightly event, it is religious ecstasy yet quite routine ordinary. Zen says, "When sleepy, sleep.” We say, "Sleep and be sleep-filled, and you will be divinely charged, kid-alive." Here the routine and ethics are naturally joined to religion, "what is" joins "what had better be toward what is beyond.” Here the is, the ought, and the as is, merge in the Beyond.

Here is a miracle quite ordinary extraordinary, actuality quite beyond us, precisely in what we practice everyday, every night-we want to be in it, aspire to fall into it, at every moment of our waking life. Are we awake? Yes. Are we asleep? Yes. Everything is one, all of a piece, and we are alive as one integral (not integrated) mustard seed, the smallest seed, sleep, always growing up to the greatest tree, "the world".

Solidly integral as one sleep-silent mustard seed, alive, the faith moves the mountain, said Jesus. Here, sleepfilled, we are Chuang Tzu's self-integral True People Divine, as the Psalmist says, "God gives to his beloved sleep."

The people are now people of nature sleep-walking free in disaster while out of it. Elijah sleeps often to eat and walk, embraced in the still small whisper of directive, to gain divine power for a divine mission. Jesus sleeps in the sea-storm to tame it. Peter sleeps the night before execution and, his chains dropped, the prison doors opened, and he just walks out. Chuang Tzu's 真人 (the true) and 神人 (the divine) join, simply naturally, with the Christian mustard-seed-miracle (Waley, 1939). Sadly, unable to understand the True Man's divine power, he appealed to the thought of idealism, a weak explanation. The Bible stories are cited from Psalms 127: 2, 1 Kings 19, Matthew 8: 23-27 (=Mark 4: 36-41 = Luke 8: 22-25), and Acts 12: 1-10; they are tacit unexplained gems in Christianity, explained here.

Sleep-awake, we are the seed in the tree, the tree in its seed, grown growing, quite cosmos-potent.

\section{Natural Alive}

Sleep-infused activity is powerful; it was the first impressive spinoff of sleep. Now here is another exciting spinoff. As the epitome of spontaneity, sleep nudges us to ponder on what "natural alive" means as the rock-bottom be-all and end-all of our living. We appreciate how impossible it is to define, describe, and/or argue for "natural alive" as the base enabling explanations and arguments; we must go story-way. Here is no ugly tree or ugly baby; nothing alive natural is ugly. Beauty is our life natural alive.

What "naturalism" we lug around since thinking began is a clumsy stand-in for tot Tommy jumping natural alive (Edwards, 1967; Reese, 1999; Runes, 1960; Rée \& Urmson, 2005). Naturalism as an ism self-defeats, considering being natural unnaturally, squeezing the running Tommy into adult toy-boxes of categories to squeeze him out of his life, well-slept. As sleep cannot be objectively approached, so natural alive as powerful of sleep can never be got by wakeful objective probe. "Natural alive" cannot be pursued as sleep cannot; the pursuit is enabled by "natural alive". None can pursue that by which to pursue. This fact can be concretely shown.

Hume tries to grasp himself grasping, and grasps a "bundle of sensations." As Hume confesses to being unable to see himself seeing, so Ryle does to being unable to complete self-description, as one must continue to describe what one describes about oneself as one describes oneself describing oneself, ad infinitum, forever unfinished (Gill, 1974; Ryle, 1949). This section offers a different approach to naturalism as a stand-in for "natural alive”. If one cannot run away from one's shadow (Chuang Tzu 31/28-29), then one cannot pursue one's self, as dear tot Tommy hopping natural alive. Confucius' and Socrates' self-examination is impossible, as none can examine that by which to examine.

Being natural is to be alive, and being alive is natural; not natural cannot be alive. And so, natural and alive are synonymous so basic primitive that no argument can explain it, for "it" the synonymy is the artesian well of life from which all arguments gush out. This artesian well of vitality got its unlimited gush-out of water of life out of sleep, of course. But we now concentrate on how "natural alive" itself is the rock-bottom base and origin of all our life-activities, including arguing and explaining.

None alive can define, explain, or argue for being natural alive. None can say, "Don't be unnatural not alive," unless the saying warns against inauthenticity, which is still impossible without alive natural. Chuang Tzu touts being self-less, name-less, desire-less, not knowing, and self-forgetting, only by assuming us all as natural alive. All following stories natural alive would have been impossible without assuming us as natural alive.

Don't you agree? Can you imagine any person dead explaining arguing for being natural alive? You cannot, right? Of course, Chuang Tzu's stories later here will tell of how "alive natural" death is, but these stories are 
told to us alive natural in terms natural alive. It is from this basic meaning of "natural alive as living" that Chuang Tzu launches its expansion of "death as natural alive". Such a revolution to vastly enrich "natural alive" would have been impossible without our initial basic understanding of "natural alive" as our living here now, as our dear tot Tommy so jumping natural alive shows us. Natural alive are obviously as basic primitive as that, to enable any thinking, defining, arguing, or explaining. So, what I will do is just tell two clusters of stories on two themes at the edge of natural alive, stories on death, and stories flooding away evil, flushing pain clean. These common stories will then naturally allude to the basic life-synonymy of natural as alive overflowing.

"But, then, you said 'naturalism' contrives as it is considers unnaturally. Isn't your consideration in this section a consideration unnatural?" A good query you raised, pal. Two points can be noted. One, "nature" is an omnibus word, so any thinking is natural unless the thinking is "contrived" argumentative. Two, a non-contrived thinking is story-thinking, telling stories that follow along with natural ongoing. Let me explain.

"Alive" is the base of sleep as sleep enhances alive. It is natural, then, that our sensitivity above toward understanding sleep clues us to resolving "alive"-dilemma, as sleep-infused life enables us to realize "alive". Lin Yutang (1950) rightly stresses what living is about and how to live it rightly, but he bypasses what "alive" is. We are enabled to approach natural alive, thanks to meditation on sleep above. So, here we go. I am aware that all acts I do are what I do, not anyone else, aware that what I do shows "I" as "I", and this showing is "alive", and I can only be aware that this showing is "alive"; I cannot explain to bring out this "that", but exhibit-story-show to demonstrate- this "that", spontaneously.

To put it another way, I cannot objectively see me seeing, but I can-indeed I must-intimately feel that I see, that this seeing is I seeing, no one else, in order to be "I" at all. Self-awareness is the core of self-identity, the axis in self-acts alive. Above all, I cannot help but be self-aware to be "I". "Cannot help" ciphers spontaneity; to be "alive" is to feel spontaneity. Spontaneity is alive, and so to capture alive is to feel spontaneity. This feeling can only be told by stories portraying how I feel spontaneity to feel "alive".

\section{6. "Story" as Thinking Living}

"But aren’t stories tall tales, mythical fantasies? How could they be trusted as actual factual?” On the contrary, what is fantastic or mythical is our ubiquitous concrete mode available, young and old, to sum up life-experiences. What is more, the fantastic mythical give us novel experiences to expand life-horizon enriched myriadfold. The world's great storyteller C. S. Lewis (1996) rightly claims as much.

Ancient science is today's mythology; science today is our mythology. Mythological stories are the be-all and end-all of science, scholarship, in all history. Myths in stories shape our world, as ethos, climate, culture, thinking-modes in feeling-patterns; they are unprovable for they are what prove the world story-shaped. "Culture" from cultus that is from colo has an interesting ramification, to dwell-inhabit, so attend to and take care of, to come to honor, respect, even worship. All this content produces "being tidy-dressed and refined", that is, cultivated, so cultured Cassell, 1968). This word-background story is relevant to what is described here.

“Aren’t stories symbols? Doesn't symbolizing just go on continually, ad infinitum, to turn meaningless?” Paul Tillich who champions religious symbols is criticized by Urban of Yale precisely that symbolic statements must be delimited by an un-symbolic statement. Tillich agrees, and makes two points. One, pan-symbolizing is meaningless; their final meaning must be fixed by the non-symbolic. Two, the non-symbolic is being itself that may mean what-is as it is (Kegley \& Bretall, 1961).

Point One says that symbol- $n$ is meaningless until it is determined by the next symbol- $n+1$. But $n+1$ itself continues symbolizing endlessly, endlessly postponed, and so its meaning cannot be fixed, so $n+1$ is meaningless. All symbols are thus meaningless until they are determined by the non-symbolic Tillich calls "being itself." And this is his Point Two, to be elaborated and pondered on in my responses here.

My responses are three. First, being itself is what is as it is, self-existing to self-mean. Concocted "self-existing”, self-sealed, differs from "self-so 自然” natural, inter-nodding self-forgotten. We will soon see their surprising "collusion", though. It is meaning-self-justified self-referred. "I am that I am" is "I mean what I mean." Gödel then proves that no system can prove itself (Dawson, 1997; Goldstein, 2005). I cannot prove me correct; only someone else does; it is a death blow to being itself as self-meaning, as an impossibility logical, epistemological, and ontological. Has Gödel himself fallen into a dilemma as liar’s paradox, though? "I prove that I cannot prove me correct" sounds ominous like "I am a liar," doesn't it? We will come to this awkward situation soon. The self appears only mirrored in the not-self. Narcissism self-kills; the self exists in the other, as the other. The next two responses explain. 
My second response is this. In Exodus 3: 14, the "I am that I am" is "I will be what I will be," a dynamics of self-transcendence in human suffering under Egyptian tyrannies, as Dr. Hertz explained, then said, "It is to assure the Israelites of the fact of deliverance, but does not disclose the manner (emphases in the original)" (Hertz, 1961). This description of the fact of Name-revelation describes God as ever God beyond God toward humans ever going beyond into their unknown future under God. God as being itself is actively be-ing itself as the élan of the Beyond, forever beyond.

Moreover, this thrust of the Beyond is a dehiscence beyond itself toward the other. Even " $\mathrm{A}$ is $\mathrm{A}$ " is to be completed by not-A as denied, "A is not not-A." A exists only in the light of not-A, denied. And so the God Beyond can only be a sociality as the Trinity and as related to his creation, as Hartshorne rightly claims, though wrongly argued for (Hartshorne, 1964). Existence inter-exists to make meaning as itself, by inter-meaning to inter-justify, as Gödel negatively proved.

If, however impossible, being itself is a static in-itself of the final meaning, then sch final meaning would dispense with all roundabout symbols, and all statements must be direct unambiguous, non-symbolic. But actuality is contingent-ambiguous, only to be alluded by indirect symbols.

My third response is this. Contingency shows that an actual existent is contingent on another existent beyond it. Contingency ciphers existence as inter-existing, i.e., as inter-symbolizing. Actuality is by nature symbolic. Existence inter-exists in being in meaning, so symbolism-chain is inherent in all existents that be-ing themselves by each symbolizing another.

Meaning erupts afresh at each symbolizing event. "Meaning” happens in the very process of symbolic referring interdependent. Existence actualizes itself in inter-confirmation, declared Gödel self-incomplete, to inter-be to inter-mean in symbols inter-linked, indirectly to evoke the point, as revelation. Stories symbolize to allude to indirect, to evoke to reveal the actual. Storytelling brings out existing actuality meant.

Now, let me put it another way, and we will realize how essential storytelling is. Two points are here. One, being natural uncannily self-feels that “I am what I am. If I feel I am correct, I am correct.” Such felt deep conviction makes genius daredevils to push their projects to a breakthrough, stunning everyone, benefitting our society as none has ever imagined before.

Anton Dvorak was told that he could not compose by his illustrious teachers, Glazunov and Rimsky-Korsakov. Coming home, Dvorak shouted at the wall, "I can, too!” And he composed the lyrical vivacious Eighth Symphony, and then the Ninth Symphony "The New World” that opens up the New World for the world of enraptured listeners. The Wright brothers were ridiculed, accused that human beings are not meant to fly, for otherwise we would have been created with wings. Defying all unanimous public opinions, the brothers managed to fly.

These geniuses contrary defy people, being self-convinced, indomitable. This inherent self-affirmation, selffelt, self-composed, is beyond direct explicit proof that is never private. Spontaneity kills explicit rationality in public, peeping at no inward conviction; Gödel may have fallen in a dilemma of "I am a liar", as he proves he cannot prove himself; doesn’t he express “I am a liar”? Self-description and self-proof as impossible show how alive natural spontaneity is beyond explicit rationality.

Point Two is this. The cul-de-sac above depicts how impossible it is to directly express "being natural", to tell of the necessity of indirect alluding, and its one crucial way is to symbolize by telling stories. Rorty tells us stories of how even philosophers tell stories to argue (Huang, 2009) for thinking usually develops in storytelling, even to itself.

Moreover, importantly, this fact also shows how spontaneity natural alive is at the base of all thinking, even explicit direct thinking, and spontaneity shows only in indirect storytelling, as we learn from history, past story. Natsume has a cat to say, "An exhaustive description of life needs 24 hours of writing about the 24 hours of a day" (Natsume, 1905) which in turn needs 24 hours to write on, ad infinitum. The "I"-milieu in everything that exists is ever "invisible", inexhaustible, an elusive ghost in things that collapse without this ghost. This ghost is sleep. Let me explain.

Thus I with things exist under this I-milieu of which I am completely ignorant. I am supported by-thereby exist in-the motherly I-milieu that is beyond me, unawares. I support my not-I, to be supported by it. Such is the co-responding in the I-milieu. This I-milieu is routinely established by sleep each day. We look forward by retrospection, exactly as sleep-infused, feeling fit well-slept. Spontaneity, natural alive, and sleep are one here, inter-elucidating into sleep-infused living, powerful invincible. Such is our essential Gospel of Self-ing, indeed. 


\section{References}

Barnes, J. (Ed.) (1995). The Complete Works of Aristotle: The Revised Oxford Translation. Princeton, NJ: Princeton University Press.

Colman, A. M. (Ed.) (2001). Dictionary of Psychology. New York: Oxford University Press.

Chuang Tzu 22/21-24 (1970). In B. Watson (Ed.) The Complete Works of Chuang Tzu (p. 237). New York: Columbia University Press.

Dawson Jr., J. W. (1997). Logical Dilemmas: The Life and Work of Kurt Gödel, Wellesley, MA: A. K. Peters.

Edwards, P. (Ed.) (1967). The Encyclopedia of Philosophy. New York: Macmillan.

Freud, S. (1989, 1913). The Interpretation of Dreams. tr. Garden City, NY: Doubleday.

Freud, S. (1950). An Outline of Psychoanalysis. New York: W. W. Norton.

Frost, R. (1995). Collected Poems, Prose, \& Plays. New York: Library of America.

Gibran, K. (1923). The Prophet. Eastford, CT: Martino Fine Books.

Gill, J. H. (Ed.) (1974). Christian Empiricism. Grand Rapids, MI: William B. Eerdmans.

Goldstein, R. (2005). Incompleteness: The Proof and Paradox of Kurt Gödel. New York: W. W. Norton.

Hartshorne, C. (1948). The Divine Relativity: A Social Conception of God. New Haven, CT: Yale University Press.

Hertz, J. H. (Ed.) (1961). The Pentateuch and Haftorahs (2nd ed.). London: Soncino Press.

Heidegger, M. (1957). Identity and Difference. Chicago: University of Chicago Press.

Huang, Y. (2009). Rorty, Pragmatism, and Confucianism. Albany, NY: State University of New York Press.

Ivker, R. S. et al. (2000). The Self-Care Guide to Holistic Medicine: Creating Optimal Health. New York: Penguin Putnam.

Jung, C. (1973). Four Archetypes. Princeton, NJ: Princeton University Press.

Jung, C. (1974). Dreams. Princeton, NJ: Princeton University Press.

Jung, C. (1974). The Essential Jung. Princeton, NJ: Princeton University Press.

Kegley, G. W., \& Bretall, R. W. (1961). The Theology of Paul Tillich. New York: Macmillan.

Kess, J. E., \& Lansdowne, H. (2005). Why Japan Matters! Victoria: Centre for Asia-Pacific Initiatives, University of Victoria.

Lewis, C. S. (1966). Of Other Worlds: Essays and Stories. San Diego, CA: Harcourt Brace and Co.

Lin, Y. T. (1937). The Importance of Living. New York: John Day.

Lin, Y. T. (1950). On American Wisdom. New York: John Day.

Mair, V. H. (1994). Wandering on the Way. tr. Mair, V. H., New York: Bantam Books.

Menuhin, Y. (1979). Introduction to Concerto for Violin, Op. 77, by Johannes Brahms: A Facsimile of the Holograph Score. Washington DC: The Library of Congress.

Natsume, S. (1905). I Am a Cat. Tokyo: New Trend Publishers.

Polanyi, M. (1959). The Study of Man. Chicago, IL: University of Chicago.

Rée, J., \& Urmson, J. O. (2005). The Concise Encyclopedia of Western Philosophy. London: Routledge.

Reese, W. L. (1999). Dictionary of Philosophy and Religion. Amherst, NY: Humanity Books.

Ricoeur, P. (1992). Oneself as Another. Chicago, IL: University of Chicago Press.

Russell, B. (1967). In Praise of Idleness. London: Unwin Books.

Runes, D. D. (1960). The Dictionary of Philosophy, 16th Edition Revised, NY: Philosophical Library.

Ryle, G. (1949). The Concept of Mind. New York: Barnes \& Noble.

Sartre, J. P. (1943). Being and Nothingness. Washington, DC: Washington Square Press.

Ssu-ma, C. C. (2005). On Sit-Forgetting. Taipei: San-Ming Publishers.

Wang, K. W. (2002). Prosepoem Talks among People. Taipei: San-Ming Publishers.

Waley, A. (1939). Three Ways of Thought in Ancient China. Stanford, CA: Stanford University Press.

Wu, K. M. (1990). The Butterfly as Companion: Meditations on the First Three Chapters of the Chuang Tzu. Albany, NY: SUNY.

Wu, K. M. (1998). On the “Logic” of Togetherness: A Cultural Hermeneutic. Leiden: Brill. 